\title{
Сезонні акумулятори тепла в схемах теплопостачання приватних житлових будинків
}

\author{
Ю. І. Дем'яненко ${ }^{1 凶}$, Т. В. Дуднік \\ ${ }^{1-2}$ Одеська національна академія харчових технологій, вул. Дворянська, 1/3, Одеса, 65082, Україна \\ $\triangle$ e-mail: ${ }^{1}$ dejurij@gmail.com \\ ORCID: ${ }^{2}$ http://orcid.org/0000-0001-8083-5048
}

\begin{abstract}
Стаття присвячена вибору сезонного акумулятора тепла (САТ) для первинного контуру теплового насосу в системі опалення та гарячого водопостачання приватного житлового будинку. В Україні в індивідуальному житловому будівництві впровадження найсучасніших ефективних систем акумуляиї̈ енергії стримується значною вартістю обладнання та відсутністю державної підтримки. Проте неухильне зростання тарифів на енергоносії спонукає домогосподарів до пошуку прийнятних варіантів САТ серед того, що пропонується споживачеві на вітчизняному ринку технологій та обладнання відновлюваної енергетики. Перехід на відновлювані джерела енергї (ВДЕ) супроводжує додаткове енергетичне завдання - узгодження нестабільних ВДЕ з навантаженням, яке також змінюється і впродовж доби, і впродовж року. Це особливо притаманне країнам, що потребують опалення в холодну пору року. Потужність, що генерується більшістю ВДЕ, істотно залежить від мінливих природних явищ. В статті запропонована німецька технологія крижаного теплоакумулятора - Wärmеритре Eisspeicher-System. Вона розроблена спеціалістами фірми Viessmanп як реакиія на заборону німеиьким природоохоронним відомством трунтових теплових насосів - як колекторних, так $і$ з трунтовими зондами. В умовах густонаселеної Німеччини $i$ високої вартості землі, відчуження значних ї̈ площ для улаштування первинних контурів ТН є неприйнятним - земля виводиться з сільськогосподарського обігу - $i$ суперечить державним інтересам. Тому використання крижаних акумуляторів як первинних контурів ТН знімає проблему як прямої, так і опосередкованої екологічної шкоди. Наведені в статті розрахунки теплового балансу первинного контуру теплового насосу Eisspeicher-System для найхолоднішого місяия опалювального періоду підтверджують можливість функціонування системи опалення та ГВП у моновалентному режимі.
\end{abstract}

Ключові слова: Сезонні акумулятори тепла; Сонячні колектори; Тепловий насос; Крижаний теплоакумулятор; Енергозбереження

\section{doi: https://doi.org/10.15673/ret.v57i2.2026}

\footnotetext{
(C) The Author(s) 2021. This article is an open access publication

This work is licensed under the Creative Commons Attribution 4.0 International License (CC BY) http://creativecommons.org/licenses/by/4.0/
}

\section{1. Вступ}

Запаси традиційних вуглеводнів, таких як нафта, газ, вугілля зовсім не $\epsilon$ нескінченними. А використання їх пов'язане 3 негативним впливом на екосистему. Одним з питань сьогодення, що найгостріше стоїть перед світовою спільнотою і потребує нагального вирішення, є питання забезпечення енергетичної та екологічної безпеки.

Суспільство не може продовжувати розвиватися в традиційний спосіб, який характеризується нераціональним використанням природних ресурсів і прогресуючим негативним впливом на навколишнє середовище. 
Згідно Директив Європейської комісії до 2022 року частка відновлюваних джерел енергії в СС становитиме близько 20\%. При цьому кількість викидів парникових газів має зменшитись щонайменше на 20\% (в порівнянні з рівнем 2000 року), а ефективність використання енергії має збільшитись на $20 \%$.

Перспективним напрямком $\epsilon$ використання теплоти сонячної енергії для комунального теплопостачання, яке може забезпечити чималі потреби в теплоті навіть в умовах територій помірного клімату. Здебільшого методи використання теплової енергії сонця загалом економічно ефективні, однак частка застосування теплової сонячної енергії доволі мала. Значно підвищити ефективність використання сонячної енергії можливо при наявності сезонного акумулятора великої теплової ємності.

\section{2. Огляд останніх джерел досліджень і публікацій}

Робота [1] присвячена застосуванню сонячних колекторів в тандемі з грунтовими тепловими насосами для теплопостачання котеджу. Розглянуто основні тенденції зміни вартості теплової енергії 3 урахуванням інвестиційної складової для невеликих систем теплопостачання з грунтовим тепловим насосом і сезонним акумулятором тепла. Автори вважають, що така схема актуальна при використанні ефективних сезонних грунтових теплових акумуляторів 3 можливістю вилучення понад 50\% тепла, накопиченого влітку. В цьому випадку невеликий термін окупності проекту, до 3-4 років, спостерігається при досягненні частки сумарної сонячної енергії в нагріванні 70-75\%. Подальше збільшення частки сонячного тепла обмежується загальною теплоємністю сезонного акумулятора.

У науково-дослідному інституті енергетики Дніпропетровського національного університету імені Олеся Гончара розроблено концепцію «Сезонний тепловий діод» [2]. Стільниковою одиницею концепції $\epsilon$ енергоактивна будівля, яка має в своєму складі енергоактивні огорожі (дахи, фасади) з геліопрофіля, тепловий насос, сезонний грунтовий акумулятор тепла, і яка використовує енергію альтернативних джерел - сонячне випромінювання, тепло грунту і повітря. Представлені результати математичного моделювання роботи системи енергоактивного теплозабезпечення будівлі

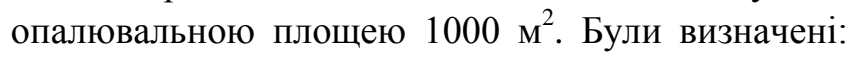

енергоактивний дах площею 1000 м $^{2}$ і теплообмінні свердловини кількістю 80 шт, глибиною 70 м кожна. Протягом року температура грунту сезонного грунтового акумулятора тепла коливається від $+37{ }^{\circ} \mathrm{C}$ до $+56{ }^{\circ} \mathrm{C}$. На робочий режим система теплозабезпечення виходить на 3-5 році експлуатації. Для забезпечення роботи в інсталяційний період і гарячого водопостачання в хмарний період енергоактивні будівлі комплектуються модульною теплонасосною станцією. Після виходу системи на робочий режим частина теплових насосів може бути демонтована для використання в нових енергоактивних будівлях.

Вочевидь, що через капітальні затрати система не може бути використана в індивідуальному житловому будівництві.

В роботі [3] представлено розрахунки акумулятору сонячної радіації для теплопостачання трисекційного п'ятипроверхового будинку. Площа секції $450 \mathrm{~m}^{2}$, теплове навантаження $E$ складає $6,123 \cdot 10^{12}$ Дж.

В основу розрахунків теплового навантаження закладені тепловтрати $50 \mathrm{BT} / \mathrm{M}^{2}$ за температури $-20{ }^{\circ} \mathrm{C}$. Теплоакумулятор складається зі 169 грунтових теплообмінників, які опускаються в свердловини діаметром 300 мм, глибиною 105 м і шагом 1,8 м, що займають площу під будинком $\left(424 \mathrm{~m}^{2}\right)$. При цьому буферна область акумулятора становитиме 19 м. Температура грунту в кінці акумулювання підніметься до $45,2{ }^{\circ} \mathrm{C}$. Сонячні колектори, розрахункова площа яких становить $41,1 \%$ від житлової площі, встановлюються на даху і на дахових козирках. Система слугує джерелом тепла для теплового насосу.

Недоліки: ємність акумулятора занижена як мінімум на $60 \%$ - нереальною є величина теплового навантаження системи теплопостачання будинку - $50 \mathrm{Bт} / \mathrm{M}^{2}$. Майже половина енергії сонячної радіації розсіюється в грунті. Значна частина енергії генерується тепловими насосами. Реалізація проекту вимагає великих капітальних затрат; свердловини 3 теплообмінниками розміщуються під будинком, а їх експлуатація, що відмічають автори, не виключає температурних змін у верхніх шарах грунту, які можуть призвести до деструктивних наслідків.

3 огляду на вищесказане облаштування такого теплоакумулятору нерентабельно: набагато дешевшою стала б система опалення та ГВП на основі грунтових зондів: відпала б необхідність в сонячних колекторах. 
Як альтернатива даній САТ наведено абсолютно теплоізольований ємнісний САТ, заповнений водою, об'ємом 36695 м $^{3}$ і висотою 27 м. Автори відмічають, що розміщення такої великої ємності з водою $є$ небезпечним не тільки під будинком, але і поряд з ним. Даних про площу сонячних колекторів та тепловтрати ємності автори не приводять.

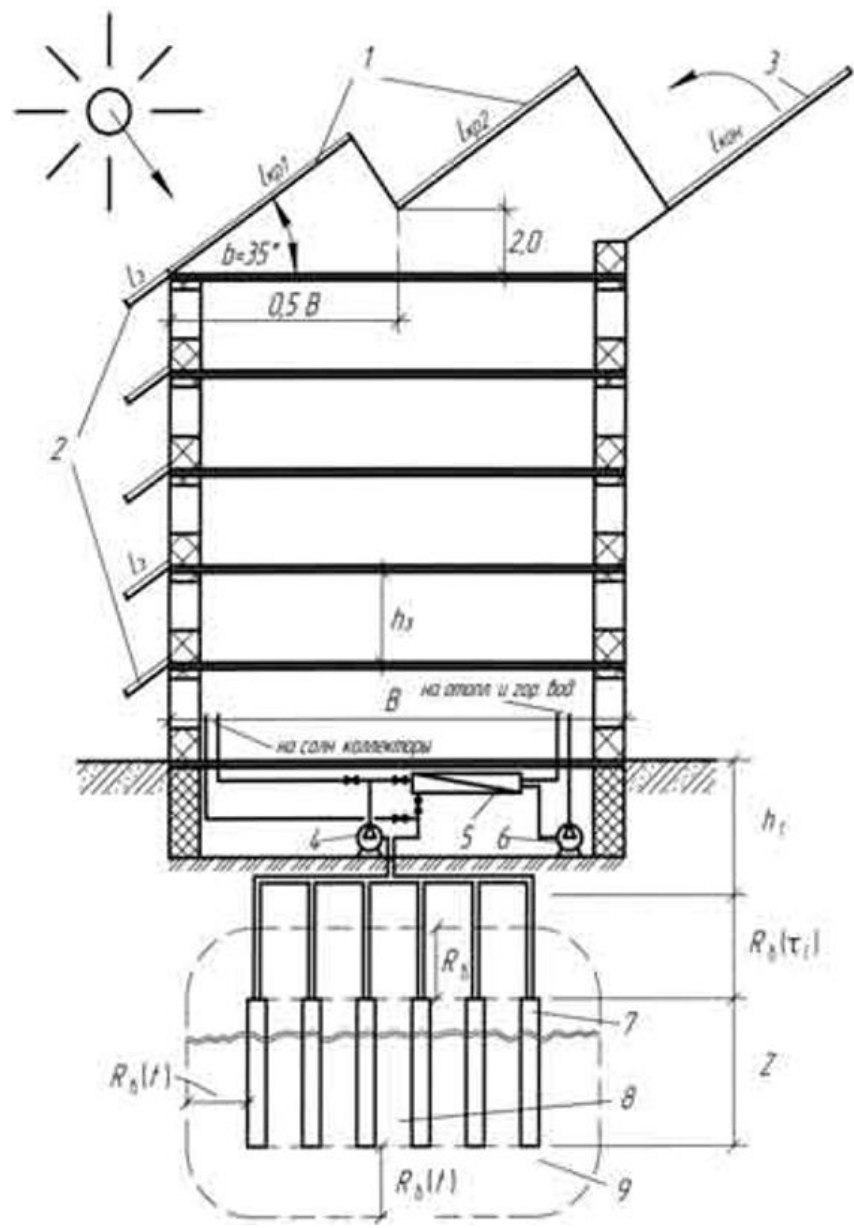

Рисунок 1 - Переріз житлового будинку:

1, 2, 3 - сонячні колектори;4 - ииркуляційний насос; 5 - тепловий насос; 6 - насоси контурів опалення та гарячого водопостачання; 7 - трунтовий теплообмінник; 8 - основна область акумуляиії; 9 - буферна підобласть акумулямії

Автори вважають, що застосування компресорного грунтового теплового насоса 3 його температурними режимами дає можливість ефективно використовувати сезонний грунтовий тепловий акумулятор за рахунок більш інтенсивного теплообміну при невисоких температурах $20-25{ }^{\circ} \mathrm{C}$ зберігання тепла в грунті. Невисокі температури сезонного зберігання, в свою чергу, знижують втрати тепла і не вимагають застосування теплових зондів 3 підвищеними робочими температурами.

У висновках відмічається, що при зниженні частки сонця в нагріванні $<65 \%$ економічні параметри таких комбінованих систем наближаються до параметрів звичайних систем з грунтовими тепловими насосами (термін окупності 5-7 років). При цьому нерентабельно будівництво дорогих буферних теплових резервуарів. У разі неінтенсивного використання сонячного тепла геліоколектори тільки погіршують економіку i ефективніше як джерелом тепла обходитися тільки грунтовим тепловим насосом.

В роботах [4, 5] на основі техніко-економічного розрахунку 3 визначенням мінімальних приведених затрат запропонована конструкція ємнісної САТ у вигляді бетонного теплоізольованого резервуару, оптимізована товщина теплоізоляції.

При розміщенні резервуару під будинком тепло, що виходить через «перекриття» теплоакумулятору, є додатнім, оскільки потрапляє в будинок, тепло через стінки і дно САТ надходить в грунт, який оточує САТ з інших боків.

Для котеджу площею $64 \mathrm{~m}^{2}$ розрахунковий об'єм САТ склав 237 м $^{3}$, площа сонячних колекторів (СК) $-73 \mathrm{~m}^{2}$. СК вакуумні, температура зарядки САТ $140{ }^{\circ} \mathrm{C}$, розрядки $-55^{\circ} \mathrm{C}$.

Всі розрахунки проводились для товщини теплової ізоляції в діапазоні $\delta_{\text {ті }}=400 \ldots 2500$ мм. Згідно графіку приведених затрат на теплову ізоляцію встановлена оптимальна їі товщина - 2300 мм.

Вказано, що при зменшенні товщини теплової ізоляції САТ з 2300 мм до 1400 мм необхідна сумарна площа сонячних колекторів збільшується на $16 \mathrm{~m}^{2}$, а розміри сезонного акумулятора теплоти на 15 см у висоту.

В роботі [6] 3 використанням математичної моделі проведено чисельні дослідження геліосистеми, що враховують взаємний вплив геліоприймача й сезонного акумулятора тепла в повністю автономному режимі роботи.

САТ $є$ монолітним теплоізольованим бетонним блоком із вбудованим теплообмінником. Автор вважає, що такі САТ об'ємом $30 \ldots 80 \mathrm{~m}^{3}$ можуть бути запропоновані для невеликих котеджів.

Об'єм САТ прийнято рівним $75 \mathrm{~m}^{3}$, ізоляція піноскляна або пропіленова товщиною 0,5 м. Результати пошуку оптимального V/A представлені на рис.2 і апроксимовані функцією виду: 


$$
\left(\frac{V}{A}\right)_{\text {опт }}=\frac{3100}{\left[4,5+\frac{U}{\tau_{\mathrm{a}}}\right]\left[\frac{Q_{0}^{\mathrm{p}}}{A}+\frac{550}{38-\frac{U}{\tau_{\mathrm{a}}}}\right]}
$$

Тут $U-$ коефіцієнт втрат тепла СК; $\tau_{\alpha}-$ оптичний показник СК.

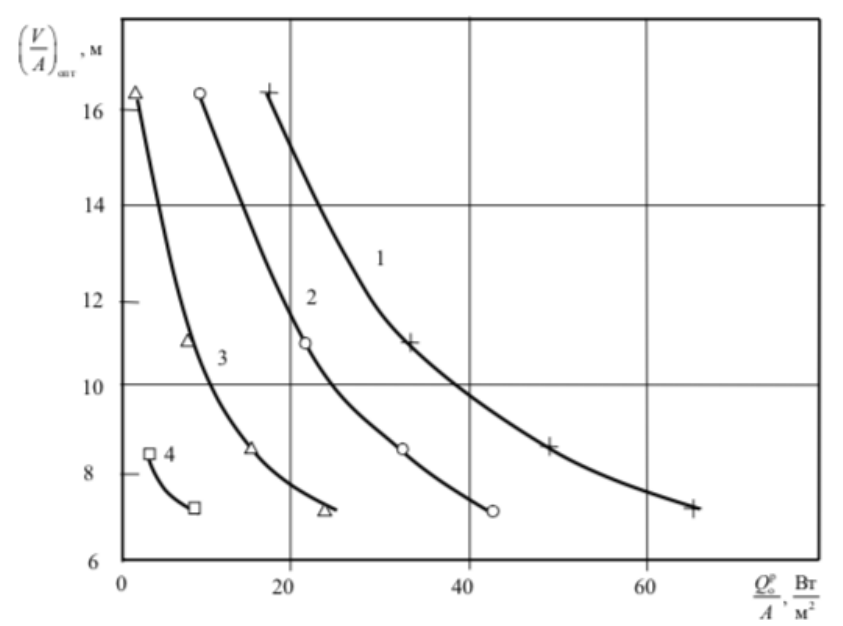

Рисунок 2 - Залежність оптимального співвідношення об 'єму CAT і площуі CK (V/A) від питомого навантаження опалення $\left(Q_{0}^{\mathrm{p}} / A\right) i$ комплексу $U /\left(\tau_{\alpha}\right)$. Значення $U /\left(\tau_{\alpha}\right), B m / \mathrm{M}^{2} \cdot K$ : $1-0,6 ; 2-3,0 ; 3-6,0 ; 4-9,6$

Доцільність вибору як теплоакумулюючого матеріалу бетону є спірною: теплоємність бетону

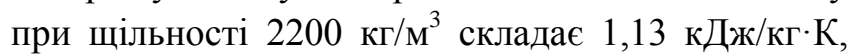
тобто майже в чотири рази менше, ніж у води. Крім того, виникає сумнів у здатності такої САТ забезпечити теплопостачання котеджу впродовж всього опалювального періоду: термічний опір закладеної в розрахунки теплоізоляції та об'єм САТ складають $R_{1}=10 \mathrm{~m}^{2} \cdot$ К/ВТ та $V_{1}=75 \mathrm{~m}^{3}$, відповідно, і значно менші проти оптимізованої в роботі [5] теплоізоляції $\left(R_{2}=22 \mathrm{~m}^{2} \cdot \mathrm{K} / \mathrm{BT} ; V_{2}=215 \mathrm{~m}^{3}\right) \mathrm{CAT}$.

На цьому фоні вигідно відрізняється система опалення $з$ тепловим акумулятором за німецькою технологією Wärmepumpe Eisspeicher-System, ро3роблена спеціалістами фірми Viessmann як реакція на заборону німецьким природоохоронним відомством грунтових теплових насосів - як колекторних, так і з грунтовими зондами [7].

В системі використовується таке явище, як енергія кристалізації води при замерзанні. Ця теплова енергія (330 кДж/кг) майже в 80 разів більша, ніж потрібно для нагрівання/охолодження води на $1{ }^{\circ} \mathrm{C}$. При цьому вода фактично не змінюе свою температуру (близько $-1{ }^{\circ} \mathrm{C}$ ) до того моменту, поки не замерзне весь ії об'єм. На основі ефекту фазового переходу води з рідкого в твердий агрегатний стан були розроблені відповідні технологічні рішення для використання енергії кристалізації.

Система складається 3 крижаного колодязю, теплового насосу і сонячно-повітряних абсорберів (рис. 3). Тепловий насос відбирає тепло з ємності. Але вода на замерзає: одночасно відбувається регенерація ємності за рахунок тепла землі, тепла повітря і сонця (за допомогою сонячно-повітряних абсорберів). Система працює в діапазоні температур замерзання/відтавання води, тобто при $-1 \ldots+1{ }^{\circ} \mathrm{C}$.

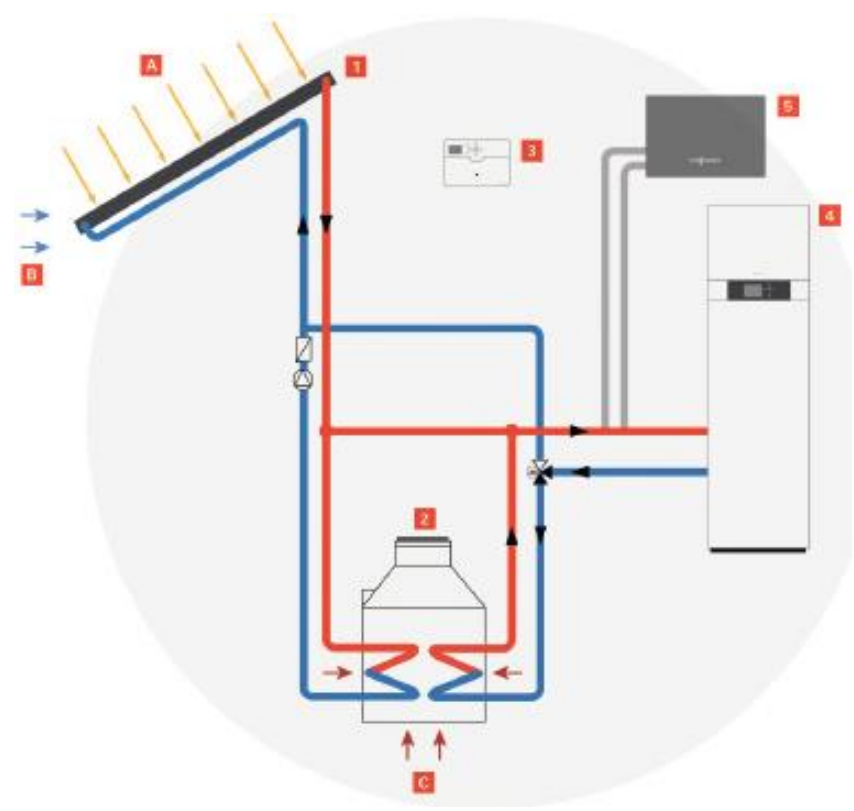

Рисунок 3 - Приниипова схема функиіонування Wärmepumpe Eisspeicher-System.

$A, B, C$-потоки енергії від сония, навколишнього повітря та трунту відповідно.

1 - сонячний колектор відкритого типу;

2 - крижаний акумулятор; 3 - контроллер теплових потоків; 4 - тепловий насос Vitocal; 5 - блок натурального (природного) охолодження

\section{3. Система опалення 3 крижаним акумуля- тором тепла}

Аналіз проведених досліджень [1-6] показує, що побудувати сезонний акумулятор тепла на основі традиційних підходів неможливо. I не тільки громіздкість , великі капітальні затрати тому причиною. Із представлених розрахункових моделей видно, що жодна 3 них гарантовано не забезпечує теплом об'єкт впродовж всього опалювального періоду. Чого не скажеш про технологію Wärmepumpe Eisspeicher-System, яка вже знайшла досить 
широке застосування в Німеччині як для індивідуальних житлових будинків, так і для багатоквартирних, офісних, торгових і виробничих будівель. Так, ще у 2014 році під Гамбургом було побудовано мікрорайон на 500 квартир (найбільша система крижаного опалення в світі), центральне опалення яких організовано за допомогою льоду в ємності на 1,5 мільйона літрів води.

Поставлено задачу для умов м. Одеси розрахувати на основі балансових рівнянь теплонадходження в крижаний колодязь (рис. 4) від грунту і сонячно-повітряних абсорберів, щоб визначити, чи достатньо цього тепла для живлення первинного контуру теплового насосу, а, отже, чи є потреба в дублюючому джерелі тепла, тобто чи може система опалення бути моновалентною.

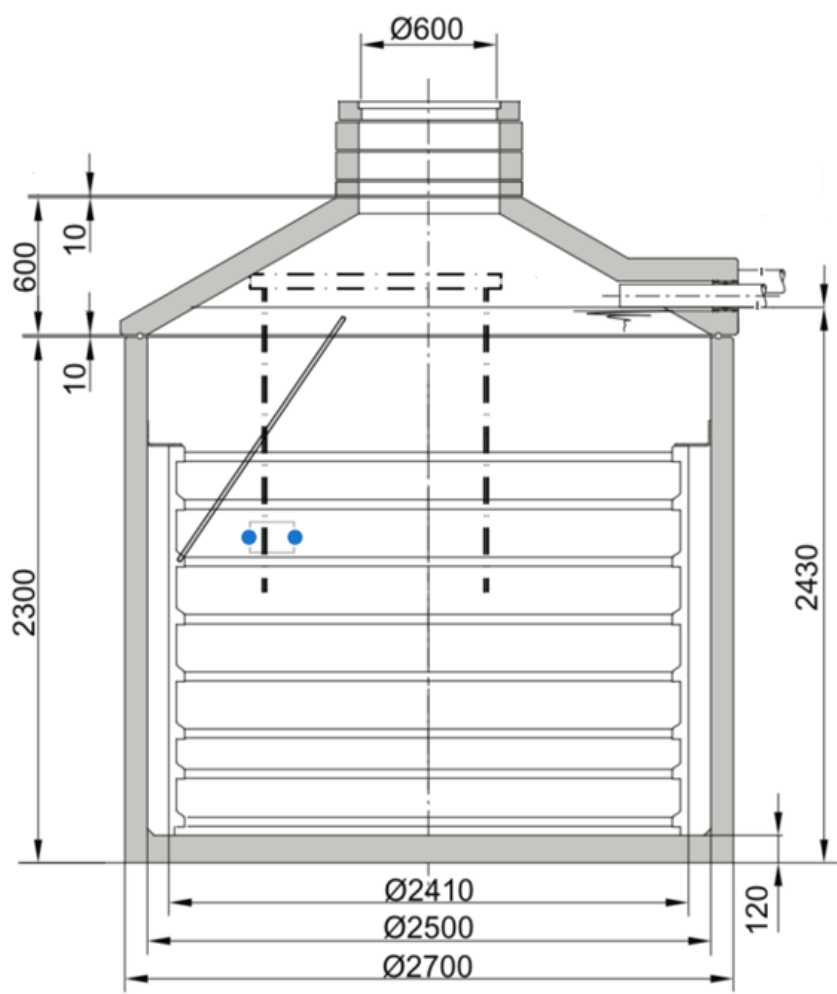

Рисунок 4 - Крижаний колодязь

Джерелом тепла для системи опалення і ГВП $\epsilon$ тепловий насос Vitocal 300 BW110 холодопродуктивністю $Q_{0}=8,4$ кВт, теплопродуктивністю $Q_{\mathrm{T}}=10,8$ кВт. Споживана потужність $N=2,4$ кВт, $\mathrm{COP}=4,50$ [8].

За розрахункової зовнішньої температури $\mathrm{t}_{3 \min }=-18{ }^{\circ} \mathrm{C}$ i температури в приміщенні $\mathrm{t}_{\mathrm{B}}=20^{\circ} \mathrm{C}$ максимальні тепловтрати будинку становитимуть 10,2 кВт. Для прикладу розглянемо січень, у якому середньомісячна температура становить $-1,3{ }^{\circ} \mathrm{C}$ [9]. Тепловтрати можна знайти з виразу:

$$
Q_{0}=\frac{Q_{0}}{Q_{\mathrm{\kappa}}} \cdot Q_{\mathrm{rв}}=\frac{8,4}{10,8} \cdot 5,72=4,45 \kappa \mathrm{BT} .
$$

Це тепло надходить із теплового колодязю, регенерація якого відбувається за рахунок теплоприпливів від грунту та із зовнішнього повітря і від сонця через сонячно-повітряні абсорбери SLK-S.

Знайдемо теплоприпливи від грунту до крижаного колодязю с температурою крижаної шуги всередині $t_{\text {кр.ш }}=(0-(-1)){ }^{\circ} \mathrm{C}$. При цьому температура грунту становить: на глибині $1,2 \mathrm{M}-5,4{ }^{\circ} \mathrm{C}$, на глибині 2,4 м $-9,5{ }^{\circ} \mathrm{C}$ [10]. Приймаємо $t_{\text {гр }}=7,5^{\circ} \mathrm{C}$

$$
\begin{aligned}
& Q_{\text {гр }}=F_{\kappa \kappa} \frac{\lambda_{\text {з.бет }}}{\delta_{\text {з.бет }}}\left(t_{\text {гр }}-t_{\text {кр.ш }}\right)==\left(\frac{\pi}{4} D_{\text {кК }}^{2}+\pi \cdot D_{\text {кК }} \cdot h_{\text {кК }}\right) \times \\
& \times \frac{\lambda_{3 . \text { бет }}}{\delta_{\text {3.бет }}}\left(t_{\text {гр }}-t_{\text {кр.ш }}\right)=\left(0,785 \cdot 2,7^{2}+3,14 \cdot 2,7 \cdot 2,9\right) \times \\
& \times \frac{2,04}{0,1}(7,5+0,5)=4946 \text { В } \text {. }
\end{aligned}
$$

Знайдемо тепло, що надходить від сонячноповітряних абсорберів. Згідно 3 [7] система оснащується вісьмома $\left(n_{\text {ск }}=8\right)$ сонячно-повітряними абсорберами SLK-S кожний площею $f_{\text {ск }}=2,34 \mathrm{~m}^{2}$.

Загальна їх площа:

$$
F_{\text {ск }}=f_{\text {ск }} \cdot n_{\text {ск }}=2,34 \cdot 8=18,72 \mathrm{M}^{2} .
$$

Питоме тепло, засвоєне сонячно-повітряними абсорберами, становитиме:

$$
q_{\text {пит }}=q_{0} \cdot n_{\text {ск }} .
$$

Для січня $q_{0}=1,25$ кВт.год/ $\mathrm{M}^{2}$, ККД сонячноповітряних абсорберів $n_{\text {ск }}=0,35$ (рис.5).

Отже,

$Q_{\mathrm{c \kappa}}^{\prime}=q_{0} \cdot \eta_{\mathrm{c \kappa}} \cdot F_{\text {ск }}=1,25 \cdot 0,35 \cdot 18,72=8,19$ кВт $\cdot$ год

або

$$
Q_{\mathrm{c \kappa}}=\frac{Q_{\text {ск }}^{\prime}}{24}=\frac{8,19}{24}=0,34 \kappa \mathrm{\kappa T} .
$$

Загальна кількість тепла, що надходить в первинний контур ТН, складає:

$$
Q_{1}=Q_{\mathrm{rp}}+Q_{\text {ск }}=4,95+0,34=5,29 \kappa \mathrm{BT}
$$




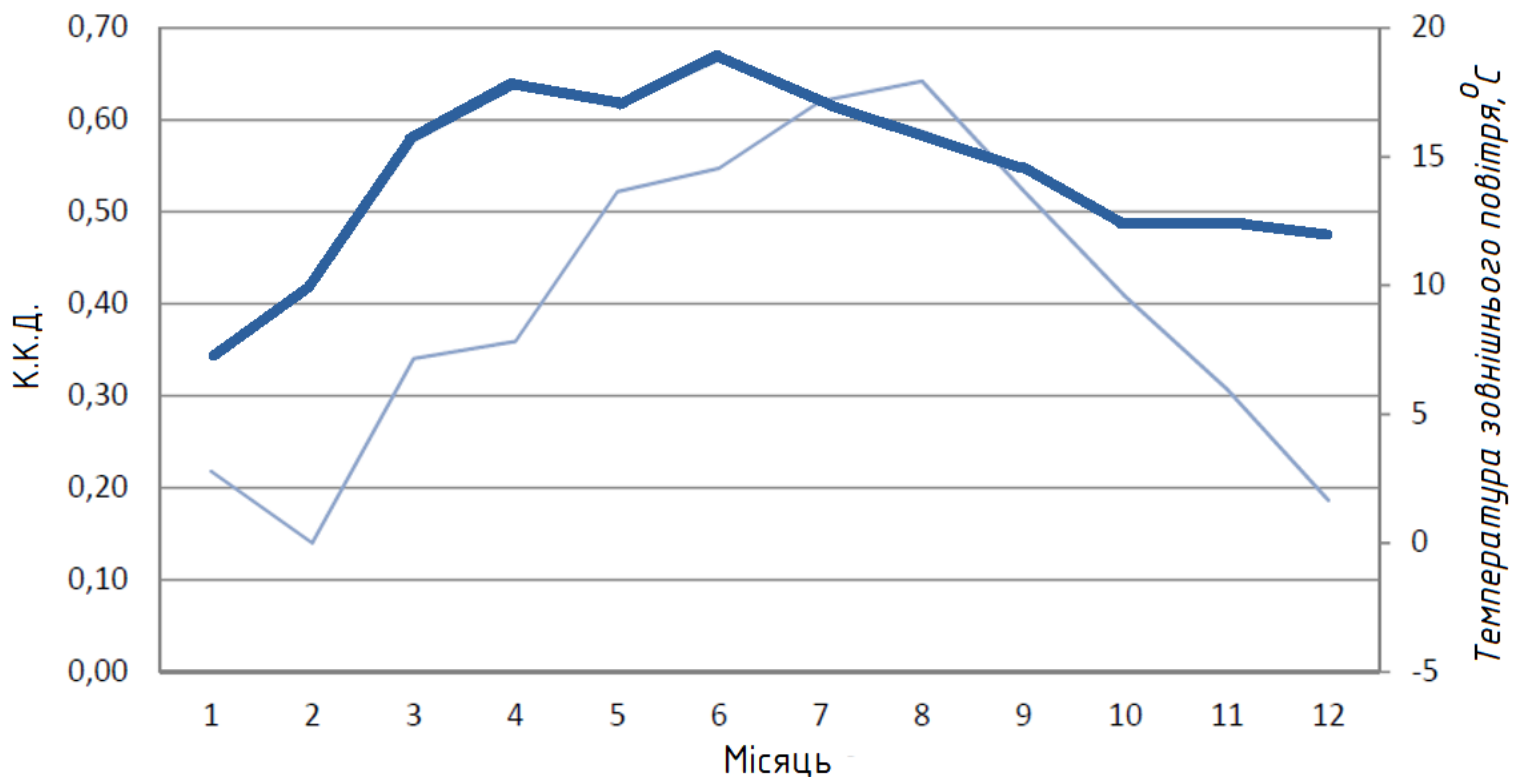

Рисунок 5 - Ефективність сонячно-повітряного абсорберу за різних температур зовнішнього повітря к.к.Ә. сонячно-повітряного абсорберу —- Температура зовнішнього повітря, ${ }^{0} \mathrm{C}$

\section{4. Висновки}

Крижаний бак - це нове низькотемпературне джерело енергії для систем опалення на основі теплових насосів. Фактично воно $є$ невичерпним. При цьому використовується таке явище, як енергія кристалізації води при замерзанні. Ця теплова енергія (330 кДж/кг) майже в 80 разів більша, ніж потрібно для нагрівання/охолодження води на $1{ }^{\circ} \mathrm{C}$. При цьому вода фактично не змінює свою температуру (близько $-1{ }^{\circ} \mathrm{C}$ ). Тепловий насос відбирає тепло $з$ баку до того моменту, поки весь об'єм води не перетвориться на «шугу» - суміш води і льоду. Водночас відбувається регенерація ємності (теплоізоляція відсутня) за рахунок тепла землі, тепла повітря і сонця (через сонячно-повітряні абсорбери). Крижаний бак розміщується в грунті, нижче глибини промерзання; оскільки він заповнений звичайною водою, це безпечно для навколишнього середовища в разі пошкоджень і витоку рідини.

Як видно із розрахунків, тепло, що надходить в первинний контур теплового насосу, перевищує тепловтрати будинку у найхолоднішому місяці: $Q_{1}>Q_{0}$. Отже, система опалення з крижаним акумулятором тепла здатна працювати в моновалентному режимі. На випадок пікових теплонавантажень, коли температура зовнішнього повітря буває нижчою за середньомісячну (таке трапляється кожні 12 років), буферна ємність системи комплектується електронагрівальною вставкою

\section{Особистий внесок авторів CRediT}

Дем'яненко Ю.І.: концептуалізація, методологія, дослідження, формальний аналіз, написання - оригінальний проект. Дуднік Т.В.: перевірка, верифікація, візуалізація, програмне забезпечення, написання - огляд та редагування, адміністрування.

\section{Література}

1. Федоров П. О., Федорова А. П. Техникоэкономические характеристики системы теплоснабжения на базе возобновляемых источников энергии в реалиях Приднепровского региона // Энергосбережение. Энергетика. Энергоаудит. 2013. - № 7. - C. 29-36.

2. Теоретичні засади побудови систем енергозабезпечення з використанням відновлюваних джерел енергії та енергоактивних обгороджувальних конструкцій // Звіт про науково-дослідну роботу. Дніпропетровський національний університет ім. Олеся Гончара. - Дніпропетровськ, 2010.

3. Накорчевский А. И., Басок Б. И., Беляева Т. Г. Проблемы грунтового аккумулирования теплоты и методы их решения // Промышленная теплотехника. - 2003. - Т. 25. - № 3. - С. 42-50.

4. Любарець О.П., Москвітіна А.С. Вибір форми і розрахунок об'єму сезонного теплоакумулятора // Вентиляція, освітлення та теплогазопостачання: наук.-техн. збірник. Відпов. ред. Е.С.Малкін. К.: КНУБА, 2016. - Вип. 20. - С. 24-38. 
5. Москвітіна А.С. Розрахунок оптимальної товщини теплової ізоляції сезонного акумулятора теплоти // Вентиляція, освітлення та теплогапостачання: наук.-техн. збірник. Відпов. ред. Е.С.Малкін. - К.: КНУБА, 2016. - Вип. 19. - С. 298-307.

6. Высочин В. В. Влияние размеров сезонного аккумулятора тепла на автономность работы гелиосистемы // Праці Одеського політехнічного університету. - 2012. - Вип. 1(38). - С. 129-132.

7. Viessmann. Vitofriocal Eisspeichersystem (Für Vitocal Sole/Wasser Wärmepumpen). Planungsan- leitung.

8. Viessmann. Техпаспорт VITOCAL 300/350, BW / BWH / WW / WWH.

9. ДСТУ-Н Б В.1.1-27:2010 «Будівельна кліматологія».

10. Расчет температуры грунта на заданной глубине. URL: http://bim-proektstroy.ru/?p=1426 (дата звернення 14.04.2021).

11. Mergenthal Nicole. Analyse eines Eisspeichersystems // Bachelorarbeit. - Hamburg, 2011.

Отримана в редакції 18.05.2021, прийнята до друку 14.06.2021

\title{
Seasonal heat accumulators in heat supply schemes of private houses
}

\author{
Yurii Demyanenko $^{\boldsymbol{\varpi}}$, Timofei Dudnik ${ }^{2}$ \\ ${ }^{1-2}$ Odessa National Academy of Food Technologies, 1/3 Dvoryanska str., Odessa, 65082, Ukraine \\ $\square$ e-mail: ${ }^{1}$ dejurij@gmail.com \\ ORCID: ${ }^{2}$ http://orcid.org/0000-0001-8083-5048
}

\begin{abstract}
The article is devoted to the choice of a seasonal heat accumulator (SHA) for the primary circuit of a heat pump in the heating and hot water supply system of a private house. In Ukraine, the implementation of state-of-the-art efficient energy storage systems in individual housing construction is constrained by the significant cost of equipment and the lack of state support. However, the steady increase in energy tariffs encourages households to look for acceptable options for SHA among what is offered to consumers in the domestic market of technologies and equipment for renewable energy. The transition to renewable energy sources (RES) is accompanied by an additional energy task - the coordination of unstable RES with the load, which also varies during the day and throughout the year. This is especially true for countries that need heating in the cold season. The power generated by most RES depends significantly on changing natural phenomena. The article proposes the German technology of ice heat accumulator - Wärmepumpe Eisspeicher-System. It was developed by Viessmann as a reaction to the German Environmental Protection Agency's ban on ground source heat pumps, both collector and ground probes. In the conditions of densely populated Germany and the high cost of land, the alienation of large areas of it for the arrangement of the primary circuits of HP is unacceptable - the land is withdrawn from agricultural circulationand is contrary to state interests. Therefore, the use of ice batteries as the primary circuits of HP removes the problem of both direct and indirect environmental damage. The calculations of the heat balance of the primary circuit of the Eisspeicher-System heat pump for the coldest month of the heating period presented in the article confirm the possibility of functioning of the heating system and hot water in monovalent mode.
\end{abstract}

Keywords: Seasonal heat accumulators; Solar collectors; Heat pump; Ice heat accumulator; Energy saving

\section{References}

1. Fedorov, P. O., Fedorova, A. P. (2013) Tekhnikoekonomicheskie kharakteristiki sistemy teplosnabzheniya na baze vozobnovlyaemykh istochnikov energii v realiyakh Pridneprovskogo regiona. Energosberezhenie. Energetika. Energoaudit (Energy saving. Power engineering. Energy audit), 7, 29-36.
2. Teoretychni zasady pobudovy system energozabezpechennia $\mathrm{z}$ vykorystanniam vidnovlyuvanykh dzherel energii ta energoaktyvnykh obgorodzhuvalnykh konstrukcii (2010) Zvit pro naukovo-doslidnu robotu. Dnipropetrovskii nacionalnii universitet imeni Olesia Gonchara. Dnipropetrovsk.

3. Nakorchevskii, A. I., Basok, B. I., Beliaeva, T. G. (2003) Problemy gruntovogo akkumulirovaniya 
teploty i metody ikh resheniya. Promyshlennaya teplotekhnika (Industrial heating technology), 25, 3, 42-50.

4. Lyubarec, O.P., Moskvitina, A.S. (2016) Vybir formy i rozrakhunok obiemu sezonnogo teploakumuliatora. Ventyliaciia, osvitlennia ta teplogazopostachannia: nauk.-tekhn. zbirnik (Ventilation, lighting and heat and gas supply: scientific and technical collection). Vidpov. red. E.S.Malkin. Kyiv: KNUBA, 20, 24-38.

5. Moskvitina, A.S. (2016) Rozrakhunok optymalnoi tovshchyny teplovoi izoliacii sezonnogo akumuliatora teploty. Ventyliaciia, osvitlennia ta teplogapostachannia: nauk.-tekhn. zbirnik (Ventilation, lighting and heat and gas supply: scientific and technical collection). Vidpov. red. E.S.Malkin. Kyiv: KNUBA, 19, 298-307.

6. Vysochin, V. V. (2012) Vliianie razmerov sezonnogo akkumuliatora tepla na avtonomnost raboty ge- liosistemy. Praci Odeskogo politekhnichnogo universitetu (Proceedings of Odessa Polytechnic University), 1(38), 129-132.

7. Viessmann. Vitofriocal ice storage system (for Vitocal brine / water heat pumps). Planning instructtions.

8. Viessmann. Technical passport VITOCAL 300/350, BW / BWH / WW / WWH.

9. DSTU-N B V.1.1-27:2010 «Budivelna klimatologiia».

10. Raschet temperatury grunta na zadannoi glubine.

Retrieved April 14, 2021, from http://bimproektstroy.ru/?p=1426.

11. Mergenthal Nicole (2011) Analysis of an ice storage system. Bachelor thesis, Hamburg. 